\title{
Milk removal in familiar and unfamiliar surroundings: concentrations of oxytocin, prolactin, cortisol and $\beta$-endorphin
}

\author{
BY RUPERT M. BRUCKMAIER, DIETER SCHAMS* AND JÜRG W. BLUM \\ Institut für Tierzucht der Universität Bern, CH-3012 Bern, Schweiz \\ *Institut für Physiologie der Technischen Universität München, \\ W-8050 Freising-Weihenstephan, Deutschland
}

(Received 21 December 1992 and accepted for publication 23 March 1993)

\begin{abstract}
SUMmary. Eight cows were machine milked either in an operating theatre or in their familiar barn. During the experiments, milk flow curves were recorded and blood samples were taken for determination of concentrations of oxytocin, prolactin, cortisol and $\beta$-endorphin. The milking cluster was attached without udder preparation. After cessation of milk flow, air was blown into the vagina for $2 \mathrm{~min}$. When milk flow had stopped again, 1 i.u. oxytocin and finally 10 i.u. oxytocin were injected to remove the remaining milk. After the start of milking, oxytocin remained basal in unfamiliar, but increased in familiar surroundings. Therefore, during normal milking only $9 \%$ of total milk was removed in unfamiliar, whereas $79 \%$ was available in familiar surroundings. In response to subsequent vaginal stimulation in the operating theatre, oxytocin increased transiently in five cows and 15-71\% of the milk was removed in these animals. In the other three cows in the operating theatre, oxytocin remained basal during vaginal stimulation, and no more milk was available. After injection of 1 i.u. oxytocin, 56 and $11 \%$, and after injection of $10 \mathrm{i} . u$. oxytocin, 13 and $8 \%$ of milk was removed in unfamiliar and familiar surroundings respectively. Concentrations of prolactin increased during the course of milking in both treatments. Premilking concentrations of cortisol and $\beta$-endorphin were elevated in unfamiliar as compared with familiar surroundings. During the course of milking, cortisol increased slightly and $\beta$-endorphin decreased in unfamiliar, whereas both hormones increased markedly during milking in familiar surroundings. We conclude that disturbed milk removal in unfamiliar surroundings is due to central inhibition of oxytocin release during normal milking and partly also to a response to vaginal stimulation. 'This blockade is possibly associated with elevated concentrations of $\beta$-endorphin.
\end{abstract}

The cisternal milk, which is stored within teat and gland cistern of the mammary gland, can be passively removed by overcoming the teat sphincter barrier. In contrast, the alveolar milk, i.e. the main portion of the stored milk, is fixed by adhesive and capillary forces within alveoli and small ducts, and must be shifted actively into the cisternal cavity during oxytocin (OT)-induced milk ejection. The importance of milk ejection for machine milking has been demonstrated (Schams et al. 1984; Gorewit \& Gassman, 1985; Mayer et al. 1991).

Milk removal can be disturbed under various conditions. Peripheral inhibition of milk ejection, i.e. disturbed action of $\mathrm{OT}$, which is released from the pituitary, was 
experimentally induced by electroshock and administration of catecholamines and ๔-adrenergic agonists (Mielke, 1981 ; Lefcourt \& Akers, 1984; Gorewit \& Aromando, 1985; Blum et al. 1989; Bruckmaier et al. 1991), whereas the milking-related OT release was not reduced by electroshock and catecholamine treatments (Blum et al. 1989). Exogenous OT could not induce milk ejection after $\alpha$-adrenergic agonist administration (Bruckmaier et al. 1991). In contrast, disturbed milk removal, which sometimes appears in primiparous parturient cows (Bruckmaier et al. 1992) and sporadically in older cows without obvious reasons (R. M. Bruckmaier, D. Schams \& J.W. Blum, unpublished results), was shown to be due to central inhibition of milk ejection, i.e. lack of or reduced release of OT in response to teat stimulation and milking. This central inhibition of milk ejection can be totally abolished by exogenous OT in physiological amounts (Bruckmaier et al. 1992).

A transient reduction of milk yield of dairy cows, presumably due to disturbed milk ejection, was also demonstrated after relocation to new housing systems (Varner et al. 1983). Relocations to unfamiliar surroundings often occur in practical farming if animals change their owner. Economic losses and udder health problems due to incomplete milk removal must be expected. The goal of this work was therefore to investigate the existence and the aetiology of disturbed milk removal in unfamiliar surroundings. In addition, the patterns of several hormones during milking, including $\beta$-endorphin, which has to our knowledge not been studied before in dairy cows, were recorded in familiar and unfamiliar surroundings.

\section{MATERIALS AND METHODS}

Eight cows (five Simmental $\times$ Red Holstein, three Swiss Braunvieh) in month 4 of their second to sixth lactation were milked on two succeeding days at 16.00 (10 h after morning milking) in their familiar barn, where they were housed attached in groups of 24 animals, and in an operating theatre. The operating theatre was characterized by bright lighting and tiled walls, whereas in the barn lighting was dim. One cow at a time was taken to the operating theatre only for milking so that the animals could not get accustomed to the new environment. In both locations the same milking equipment was used, incorporating a strain gauge unit permitting continuous milk flow recordings (Schams et al. 1984). The milk flow signal (weight gain differentiated by time) was continuously conveyed to a strip chart recorder. In both treatments, the milking cluster was attached without any udder preparation. After milk flow had ceased for $3 \mathrm{~min}$, vaginal stimulation was applied by blowing air repeatedly into the vagina for $2 \mathrm{~min}$. After flow had stopped again, a physiological dosage (1 i.u.) and finally a supraphysiological dosage (10 i.u.) of OT was injected intravenously (i.v.) to remove the remaining milk.

Before the first experiment, an indwelling catheter was inserted into the left jugular vein for collection of blood samples $(10 \mathrm{ml})$ at $1 \mathrm{~min}$ intervals from $2 \mathrm{~min}$ before the start of milking until the i.v. injection of $10 \mathrm{i} . \mathrm{u}$. OT at the end of milking. Blood samples were treated with heparin (50 USP units $/ \mathrm{ml}$ blood) to prevent coagulation, cooled on ice and centrifuged immediately after the experiment at $1500 \mathrm{~g}$ for $20 \mathrm{~min}$. The plasma was stored at $-20^{\circ} \mathrm{C}$ in several portions for determination of hormones.

Concentrations of oxytocin, prolactin (PRL) and cortisol were determined by radioimmunoassay as described previously by Schams (1983), Bruckmaier et al. (1992) and Blum et al. (1985) respectively. Concentrations of $\beta$-endorphin were determined radioimmunologically using a kit (Incstar Corporation 46065, Stillwater, 
Table 1. Absolute and relative milk yields in unfamiliar and familiar surroundings during normal milking, and in response to vaginal stimulation and exogenous oxytocin

(Values are means \pm sem for $n=8$ )

\begin{tabular}{|c|c|c|c|c|c|}
\hline \multirow[b]{3}{*}{ Period... } & \multicolumn{4}{|c|}{ (Values are means \pm SEM for $n=8$ ) } & \\
\hline & \multicolumn{5}{|c|}{ Unfamiliar surroundings } \\
\hline & $\begin{array}{l}\text { Normal } \\
\text { milking }\end{array}$ & $\begin{array}{c}\text { Vaginal } \\
\text { stimulation }\end{array}$ & $\begin{array}{c}1 \text { i.u. } \\
\text { oxytocin }\end{array}$ & $\begin{array}{c}10 \mathrm{i} . \mathrm{u} . \\
\text { oxytocin }\end{array}$ & Total \\
\hline \multirow[t]{2}{*}{$\begin{array}{l}\text { Milk yield, kg } \\
\text { Relative milk yield, \% }\end{array}$} & $\begin{array}{c}1 \cdot 2 \pm 0 \cdot 3 \\
9 \pm 2\end{array}$ & $\begin{array}{l}2 \cdot 8 \pm 1 \cdot 3 \\
22 \pm 9\end{array}$ & $\begin{array}{l}7 \cdot 2 \pm 0 \cdot 8 \\
56 \pm 8\end{array}$ & $\begin{array}{l}1 \cdot 6 \pm 0 \cdot 2 \\
13 \pm 2\end{array}$ & $\begin{array}{c}12 \cdot 8 \pm 0 \cdot 5 \\
100\end{array}$ \\
\hline & \multicolumn{5}{|c|}{ Familiar surroundings } \\
\hline Period ... & $\begin{array}{l}\text { Normal } \\
\text { milking }\end{array}$ & $\begin{array}{c}\text { Vaginal } \\
\text { stimulation }\end{array}$ & $\begin{array}{c}1 \text { i.u. } \\
\text { oxytocin }\end{array}$ & $\begin{array}{c}10 \mathrm{i} . \mathrm{u} \\
\text { oxytocin }\end{array}$ & Total \\
\hline $\begin{array}{l}\text { Milk yield, } \mathrm{kg} \\
\text { Relative milk yield, \% }\end{array}$ & $\begin{array}{c}10 \cdot 3 \pm 0 \cdot 7 \\
79 \pm 3\end{array}$ & $\begin{array}{l}0 \cdot 3 \pm 0 \cdot 2 \\
2 \pm 2\end{array}$ & $\begin{array}{l}1 \cdot 4 \pm 0 \cdot 3 \\
11 \pm 3\end{array}$ & $\begin{array}{c}1 \cdot 0 \pm 0 \cdot 4 \\
8 \pm 1\end{array}$ & $\begin{array}{c}13 \cdot 0 \pm 0 \cdot 6 \\
100\end{array}$ \\
\hline
\end{tabular}

MN 55082, USA). The method has been shown to be suitable for the determination of $\beta$-endorphin in cattle (Bruckmaier et al. 1992). Within-assay coefficients of variation were $<10 \%$ for all radioimmunoassays employed.

\section{Statistical analyses}

For statistical evaluation and presentation of hormone results, mean values for periods of 2 min were calculated before the start of milking (two blood samples, phase I), from $1 \mathrm{~min}$ after the start of milking (three blood samples, phase II), from $1 \mathrm{~min}$ after the start of vaginal stimulation (three blood samples, phase III) and 2 min before the injection of 10 i.u. OT at the end of milking (three blood samples, phase IV). Values are presented as means \pm SEM. Changes during the course of experiment and differences between treatments were tested for significance $(P<0.05)$ by means of Wilcoxon's signed rank test employing the SAS program package (release 6.04) (SAS, 1990).

\section{Milk yields}

\section{RESULTS}

Mean total yields (Table 1) at experimental milkings were similar in unfamiliar and familiar surroundings. As shown in Table 1 and Fig. 1, in the operating theatre only a small amount of the total milk was obtained during normal milking, whereas most of the milk was removed in the barn. In response to subsequent vaginal stimulation, in the operating theatre no milk was obtained in three animals and $15-71 \%$ could be removed in five animals (mean $22 \pm 9 \%$ ). In the barn, small amounts of the total milk were obtained in response to vaginal stimulation. After injection of $1 \mathrm{i} . \mathrm{u}$. OT, the main portion of milk was removed in the operating theatre and a little more milk was obtained in the barn. After injection of $10 \mathrm{i} . \mathrm{u}$. OT, another small amount of milk was removed in both treatments.

\section{Oxytocin concentrations}

Plasma concentrations of OT (Fig. 1, Table 2) before milking (phase I) were similarly low in unfamiliar and familiar surroundings. After the start of milking (phase II), concentrations of OT remained basal in unfamiliar but increased markedly in familiar surroundings. During vaginal stimulation (phase III), OT increased only moderately and transiently in five cows and not at all in three cows (from which no milk was removed during this period) in the operating theatre. In the 


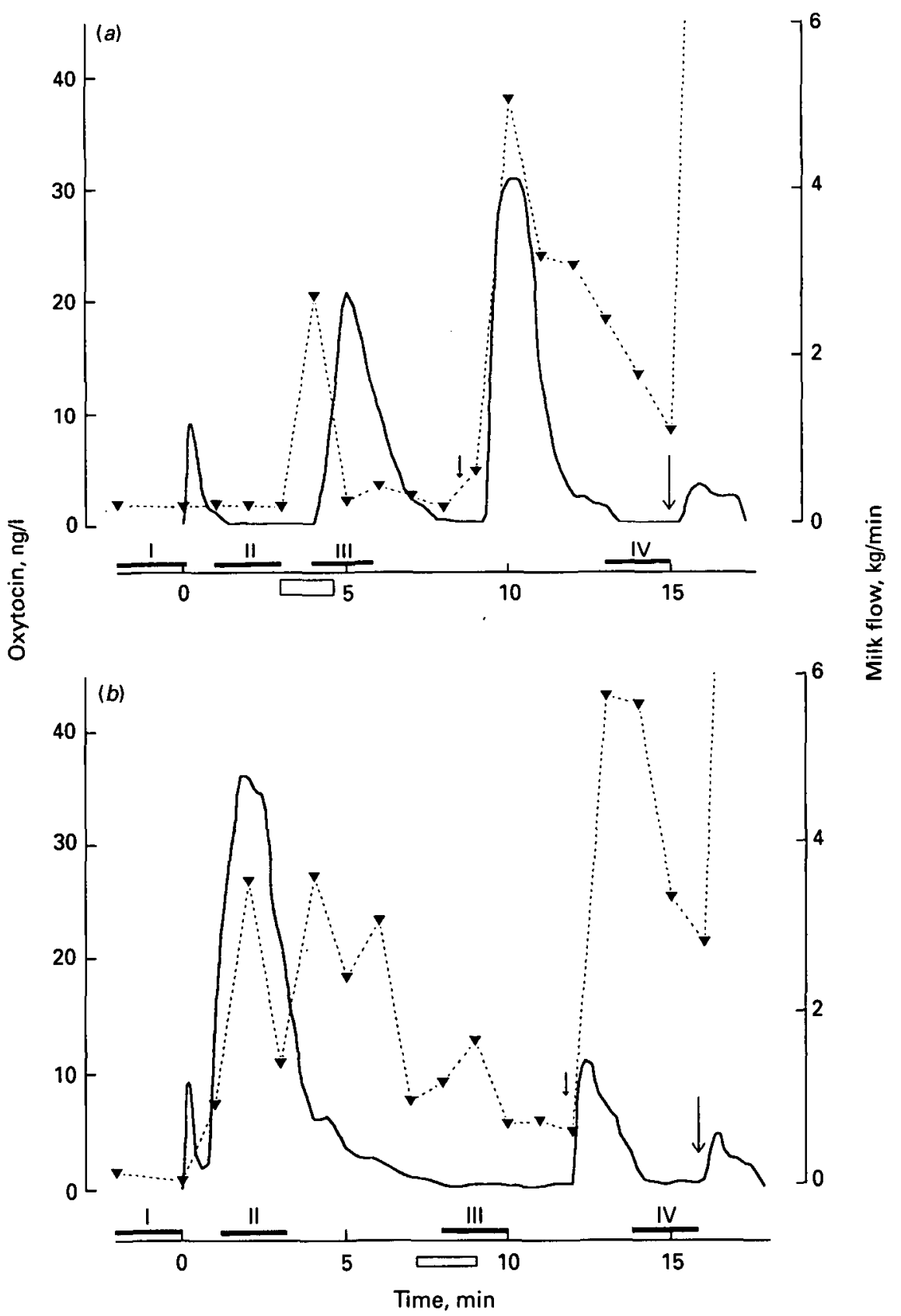

Fig. 1. Concentration of oxytocin $(\boldsymbol{\nabla})$ and milk flow late $(-)$ in one cow before and during milking in $(a)$ unfamiliar and $(b)$ familiar surroundings. $\leftrightharpoons$, Vaginal stimulation; 0 , start of milking; small arrow, i.v. injection of 1 i.u. oxytocin; large arrow, i.v. injection of 10 i.u. oxytocin. _-, Phases I-IV (see text).

barn, OT remained elevated or increased slightly during vaginal stimulation. After injection of 1 i.u. OT (phase IV), blood concentrations of OT were similarly high in unfamiliar and familiar surroundings. After injection of $10 \mathrm{i} . \mathrm{u}$. OT, plasma concentrations of OT increased beyond the range of the standard curve of the radioimmunoassay (to $400-500 \mathrm{ng} / \mathrm{l}$ ) in both groups. 
Table 2. Hormone levels in blood plasma before milking (phase I), after the start of milking (phase II), in response to vaginal stimulation (phase III) and at the end of milking (phase IV) in unfamiliar and familiar surroundings

(Values are means $\pm \mathrm{SEM}$ for $n=8$ )

\begin{tabular}{lcccc} 
& \multicolumn{5}{c}{ Cnfamiliar surroundings } \\
\cline { 2 - 5 } Phase $\ldots$ & I & II & III & IV \\
Oxytocin, ng/l & $1 \cdot 5 \pm 0 \cdot 3^{\mathrm{a}}$ & $2 \cdot 1 \pm 0 \cdot 4^{\mathrm{a}}$ & $3 \cdot 7 \pm 0 \cdot 7^{\mathrm{a}}$ & $27 \cdot 1 \pm 0 \cdot 8^{\mathrm{b}}$ \\
Prolactin, $\mu \mathrm{g} / \mathrm{l}$ & $84 \pm 17^{\mathrm{a}}$ & $83 \pm 15^{\mathrm{a}}$ & $118 \pm 33^{\mathrm{b}}$ & $206 \pm 49^{\mathrm{c}}$ \\
Cortisol, $\mu \mathrm{g} / \mathrm{l}$ & $8 \cdot 7 \pm 0 \cdot 7^{\mathrm{a} *}$ & $8 \cdot 9 \pm 0 \cdot 8^{\mathrm{a}}$ & $8 \cdot 4 \pm 1 \cdot 0^{\mathrm{a}}$ & $11 \cdot 2 \pm 1 \cdot 1^{\mathrm{b}}$ \\
$\beta$-Endorphin, ng/l & $16 \cdot 1 \pm 1 \cdot 9^{\mathrm{a} *}$ & $13 \cdot 7 \pm 1 \cdot 6^{\mathrm{ab}}$ & $13 \cdot 3 \pm 1 \cdot 3^{\mathrm{b}}$ & $11 \cdot 7 \pm 1 \cdot 1^{\mathrm{b}}$ \\
& \multicolumn{5}{c}{ Familiar surroundings } \\
Phase ... & \multicolumn{5}{c}{$\mathrm{I}$} & $\mathrm{II}$ & $\mathrm{III}$ & $\mathrm{IV}$ \\
Oxytocin, ng/l & $1 \cdot 5 \pm 0 \cdot 2^{\mathrm{a}}$ & $20 \cdot 9 \pm 5 \cdot 1^{\mathrm{b}}$ & $26 \cdot 3 \pm 10 \cdot 6^{\mathrm{b}}$ & $30 \cdot 9 \pm 3 \cdot 3^{\mathrm{c}}$ \\
Prolactin, $\mu \mathrm{g} / 1$ & $68 \pm 17^{\mathrm{a}}$ & $106 \pm 28^{\mathrm{b}}$ & $286 \pm 49^{\mathrm{c}}$ & $297 \pm 36^{\mathrm{c}}$ \\
Cortisol, $\mu \mathrm{g} / \mathrm{l}$ & $3 \cdot 8 \pm 0 \cdot 6^{\mathrm{a}}$ & $4 \cdot 5 \pm 0 \cdot 6^{\mathrm{a}}$ & $6 \cdot 2 \pm 0 \cdot 9^{\mathrm{b}}$ & $7 \cdot 7 \pm 0 \cdot 9^{\mathrm{b}}$ \\
$\beta$-Endorphin, ng/l & $8 \cdot 3 \pm 0 \cdot 8^{\mathrm{a}}$ & $8 \cdot 3 \pm 1 \cdot 0^{\mathrm{a}}$ & $8 \cdot 6 \pm 1 \cdot 0^{\mathrm{a}}$ & $10 \cdot 4 \pm 1 \cdot 3^{\mathrm{b}}$
\end{tabular}

$a, b, c$ Means of phases without common subscript letters are significantly different within row and treatment $(P<0 \cdot 05)$.

* Vleans of phase I within trait are significantly different between treatments $(P<0.05)$.

\section{Prolactin concentrations}

Concentrations of PRL (Table 2) before milking (phase I) were slightly but not significantly higher in unfamiliar than in familiar surroundings. During phase II, PRL remained basal or increased slightly in some animals in unfamiliar surroundings, whereas in familiar surroundings, PRL increased markedly during phase II. In response to vaginal stimulation (phase III), PRL increased moderately in the operating theatre and markedly in the barn, and increased further in both treatments until the end of milking (phase IV).

\section{Cortisol concentrations}

Basal concentrations of cortisol (phase I) were significantly elevated in unfamiliar as compared with familiar surroundings (Table 2). During the course of milking, cortisol increased continuously in familiar surroundings, whereas in unfamiliar surroundings the concentrations remained high and unchanged until phase III and finally increased further to the end of milking (phase IV).

\section{$\beta$-Endorphin concentrations}

Basal concentrations of $\beta$-endorphin (phase I) were significantly higher in unfamiliar than in familiar surroundings (Table 2). $\beta$-Endorphin values in the barn remained stable until phase III and increased slightly $(P<0.05)$ at the end of milking. In contrast, $\beta$-endorphin in the operating theatre decreased during the whole course of milking.

\section{DISCUSSION}

Basal concentrations (phase I) of OT were similar in unfamiliar and familiar surroundings and in a range found previously (Schams et al. 1984; Mayer et al. 1991 ; Bruckmaier et al. 1992). Basal concentrations of PRL were relatively high in both treatments, probably because the experiments were conducted during the summer (June) (Schams \& Reinhardt, 1974). Basal concentrations of cortisol and $\beta$-endorphin were significantly higher and those of PRL tended to be higher in 
unfamiliar than in familiar surroundings. Obviously, relocation to unfamiliar surroundings was a considerable emotional stress for the animals. Elevated cortisol concentrations in cows were previously observed after relocation (Varner et al. 1983), during transportation (Bremel \& Gangwer, 1978) and during isolation from companion animals (Willett \& Erb, 1972) as a reaction to and an indicator for stress conditions. Adrenocorticotropin (ACTH), i.e. the releasing factor for cortisol, and $\beta$-endorphin are derived from a common precursor in the pituitary (Eipper \& Mains, 1980) and were shown to be released concomitantly in stressed rats (Guillemain et al. 1977). Furthermore, the administration of opioid peptides produced negative feedback for the release of cortisol in cows (Nanda et al. 1992). Thus it is likely that there is also a common regulation of ACTH and $\beta$-endorphin release in cows, and the simultaneously elevated premilking concentrations of $\beta$-endorphin and cortisol in unfamiliar surroundings are therefore not surprising. Furthermore, it has been suggested that endogenous opioid concentrations modulate PRL release in several species (Barb et al. 1991). It is possible that the elevated basal concentrations of $\beta$-endorphin were responsible for higher concentrations of PRL in unfamiliar surroundings. This is consistent with the finding that administration of the opioid antagonist naloxone suppresses PRL concentrations in cows (Gregg et al. 1986).

During normal milking, i.e. tactile stimulation by the milking cluster, OT was released in a normal manner in the barn and was succeeded by alveolar milk ejection (Schams et al. 1984; Mayer et al. 1991; Bruckmaier et al. 1992). Therefore the main portion of milk stored within the udder was removed during this period. Owing to lack of previous stimulation, the milk flow curve in the barn followed a bimodal pattern, demonstrating delayed milk ejection after the start of milking (Mayer et al. 1984). The advantage of milking without premilking stimulation in this experiment was the possibility of estimating the 'pre-ejection' milk fraction (cisternal milk) from the first peak of the bimodal milk flow curve. This fraction could be compared with the milk fraction removed during normal milking in unfamiliar surroundings. Indeed, OT release during normal milking in the operating theatre was inhibited, milk ejection did not occur, and only a fraction roughly similar to that of the first peak in the barn was removed. This fraction is thought to be the cisternal milk. Whereas an inhibitory action of elevated concentrations of cortisol on O'T release is not likely (Mayer \& Lefcourt, 1987), inhibitory effects of endogenous opioid peptides on OT release and milk ejection have been reported previously in rats (Bicknell et al. 1988), rabbits (Tindal \& Blake, 1986), and mice (Haldar \& Bade, 1981). It is possible that the lack of oxytocin release during normal milking in unfamiliar surroundings was also due to high $\beta$-endorphin concentrations within the hypothalamus-pituitary system, which are reflected by elevated $\beta$-endorphin concentrations in the peripheral blood.

In response to vaginal stimulation, sufficient OT was released to induce milk ejection in primiparous cows with disturbed milk removal and more OT than in response to teat stimulation was released in normal cows (Bruckmaier et al. 1992). In this investigation, only a moderate and transient amount of OT or none at all was released during vaginal stimulation in the operating theatre, demonstrating a much stronger inhibition of OT release in unfamiliar surroundings than in primiparous parturient cows. Therefore, only a small amount or no milk was removed in response to vaginal stimulation.

After injection of OT, milk removal was normal in the operating theatre, and the milk flow rates were comparable to those in the barn. Peripheral inhibition of milk removal, which occurs after catecholamine administration together with normal 
release of OT and lack of mammary action of endogenous and exogenous OT (Blum et al. 1989 ; Bruckmaier et al. 1991), could therefore be excluded in this investigation. Milk yield at the end of milking, i.e. after injections of OT, was similar in unfamiliar and familiar surroundings in this study. A reduction in milk synthesis and secretion, as was observed during long-term elevated corticoid concentrations such as those that occur in Escherichia coli endotoxin mastitis (Varner et al. 1983; Bruckmaier et al. 1993) could be excluded.

During the course of milking, concentrations of PRL and cortisol increased only moderately in unfamiliar surroundings, whereas those of $\beta$-endorphin actually decreased. This was possibly due to the already elevated concentrations of PRL, cortisol and $\beta$-endorphin before milking. Nevertheless, because there is some PRL and cortisol released during milking, the afferent pathways responsible for the release of PRL and cortisol seem to be still intact, although the missing or reduced release of PRL during early milking indicates reduced action of the milking stimulus. In familiar surroundings, the release of PRL and cortisol during milking occurred as previously demonstrated (Koprowski \& Tucker, 1973; Reinhardt \& Schams, 1974; Bruckmaier et al. 1992). Increasing concentrations of $\beta$-endorphin during milking in the barn were to the best of our knowledge demonstrated for the first time in dairy cows. Increasing $\beta$-endorphin concentrations, probably of hypothalamic origin, were demonstrated during suckling in ewes (Gordon et al. 1987). $\beta$-Endorphin is thought to be responsible for delayed cyclic activity in humans (Quigley \& Yen, 1980; Ellingboe et al. 1982) and in cattle (Myers et al. 1989; Barb et al. 1991). There may be an association of increasing $\beta$-endorphin concentration during milk removal and suckling- or milking-induced suppression of cyclic activity in cattle (Williams, 1990).

This study was supported by the Swiss National Foundation (Grant 3228781.90). The expert performance of hormone assays by Ms G. Bachmeier, Institut für Physiologie, Technische Universität München and by Ms C. Morel and Ms Y. Zbinden, Institut für Tierzucht, Universität Bern, is greatly appreciated.

\section{REFERENCES}

Barb, C. R., Kraeling, R. R. \& Rampacek, G. B. 1991 Opioid modulation of gonadotropin and prolactin secretion in domestic farm animals. Domestic Animal Endocrinology $815-27$

Bicknell, R. J., Zhao, B.-G., Chapman, C., Heavens, R. P. \& Slrinathinghu, D. J. S. 1988 Opioid inhibition of secretion from oxytocin and vasopressin nerve terminals following selective depletion of neurohypophysial catecholamines. Neuroscience Letters $93281-286$

Blum, J. W., Jans, F., Moses, W., Fröhli, D., Zemp, M., Wanner, M., Hart, I. C., Thun, R. \& Keller, U. 1985 Twentyfour-hour pattern of blood hormone and metabolite concentrations in high-yielding dairy cows : effects of feeding low or high amounts of starch, or crystalline fat. Zentralblatt für Veterinärmedizin 32A $401-418$

Blum, J. W., Schams, D. \& Bruckmaier, R. 1989 Catecholamines, oxytocin and milk removal in dairy cows. Journal of Dairy Research 56 167-177

BREMEL, R. D. \& GaNGWER, M. I. 1978 Effect of adrenocorticotropin injection and stress on milk cortisol content. Journal of Dairy Science 61 1103-1108

Bruckmaler, R., MaYer, H. \& Schams, D. 1991 Effects of $\alpha$-and $\beta$-adrenergic agonists on intramammary pressure and milk flow in dairy cows. Journal of Dairy Research $58411-419$

Bruckmaiek, R. M., Schällibaum, M. \& Blum, J. W. 1993 E. coli endotoxin-induced mastitis in dairy cows: changes and importance of insulin-like growth factor I and oxytocin. Milchwissenschaft 48 374-378.

Brcckmaier, R. II., Schams, D. \& Blum, J. W. 1992 Aetiology of disturbed milk ejection in parturient primiparous cows. Journal of Dairy Research 59 479-489

Eipper, B. A. \& Mains, R. E. 1980 Structure and biosynthesis of pro-adrenocorticotropin/endorphin and related peptides. Endocrine Reviews 1 1-27

Elingboe, J., Veldhuis, J. D., Mendelson, J. H., Kuehnle, J. C., Mello, N. K. \& Holbrook, P. G. 1982 Effect of endogenous opioid blockade on the amplitude and frequency of pulsatile luteinizing hormone secretion in normal men. Journal of Clinical Endocrinology and Metabolism 54 854-857 
Gordon, K., Renfree, M. B.. Short. R. I. \& C'lakke. I. J. 1987 Hypothalamo-pituitary portal blood concentrations of $\beta$-endorphin during suckling in the ewe. Journal of Reproduction and Fertility $79397-408$

Gorkwit, R. C. \& Aromando, M. C. 1985 Mechanisms involved in the adrenalin-induced blockade of milk ejection in dairy cattle. Proceedings of the Society for Experimental Biology and Medicine 180 340-347

Gokewit, R. C. \& Gassman, K. B. 1985 Effects of duration of udder stimulation on milking dynamies and oxytocin release. Journal of Dairy Science 68 1813-1818

Grego, D. W., Moss, G. E., Hudgess, R. E. \& Malves, P. Y. 1986 Endogenous opioid modulation of luteinizing hormone and prolactin secretion in postpartum ewes and cows. Journal of Animal Science $\mathbf{6 3}$ 838-847

Gulllemain, R., Vargo, T., Rossier, J., Minick, S., Livg, N., Rivier, C., Vale, IV. \& Bloom, F. 1977 $\beta$-Endorphin and adrenocorticotropin are secreted concomitantly by the pituitary gland. Science 197 $1367-1369$

HALDAR, J. \& BADE, V. 1981 Involvement of opioid peptides in the inhibition of oxytocin release by heat stress in lactating mice. Proceedings of the Society for Experimental Biology and Medicine $16810-14$

Koprowski, J.A. \& Tucker, H. A. 1973 Bovine serum growth hormone, corticoids and insulin during lactation. Endocrinology 93 645-651

Lefcolrt, A. M. \& AkERs, R. M. 1984 Small increases in peripheral noradrenalin inhibit the milk-ejection response by means of a peripheral mechanism. Journal of Endocrinology $100337-344$

Mayer, H., Bruckmater, R. \& Schams, D. 1991 Lactational changes in oxytocin release, intramammary pressure and milking characteristies in dairy cows. Journal of Dairy Research $58159-169$

MAYER. H. \& Lefcourt, A. M. 1987 Failure of cortisol injected prior to milking to inhibit milk ejection in dairy cattle. Journal of Dairy Research 54 173-177

Mayer, H., Schams, D., Worstorf, H. \& Prokopp, A. 1984 Secretion of oxytocin and milk removal as affected by milking cows with and without manual stimulation. Journal of Endocrinology 103 355-361

MıELk E, H. 1981 [Recent results from studies on inhibited milk ejection.] Monatshefte für Veterinärmedizin 36 $525-530$

Myers, T. R., Myers, D. A., GregG, D. W. \& Moss, G. E. 1989 Endogenous opioid suppression of release of luteinizing hormone during suckling in postpartum anestrous beef cows. Domestic Animal Endocrinology 6 $183-190$

Nanda, A.S., Dobson, H. \& WARd, W. R. 1992 Opioid modulation of the hypothalamo-pituitary-adrenal axis in dairy cows. Domestic Animal Endocrinology 9 181-186

QuigLeY, M. E. \& YEN, S.S. C. 1980 The role of endogenous opiates on LH secretion during the menstrual cycle. Journal of Clinical Endocrinology and Metabolism 51 179-181

ReinhaRdt, V. \& Schams, D. 1974 Analysis of teat stimulation as specific stimulus for prolactin in cattle. Neuroendocrinology 14 289-296

SAS 1990 SAS User's Guide: Statistics. Cary, NC: SAS Institute

Sch AMs, D. 1983 Oxytocin determination by radioimmunoassay. III. Improvement to subpicogram sensitivity and application to blood levels in cyclic cattle. Acta Endocrinologica 103 180-183

Schams, D., Mayer, H., Prokopp, A. \& Worstorff, H. 1984 Oxytocin secretion during milking in dairy cows with regard to the variation and importance of a threshold level for milk removal. Journal of Endocrinology $102337-343$

Schams, D. \& ReinhardT, V. 1974 Influence of the season on plasma prolactin level in cattle from birth to maturity. Hormone Research 5 217-226

TINDAL, J. S. \& BLAKE, L. A. 1986 Central inhibition of oxytocin release in the rabbit: role of the midbrain. Journal of Endocrinology $109405-409$

Varner, M. A., Johnson, B. H., Britt, J. H., McDaniel, B. T. \& Mochrie, R. D. 1983 Influence of herd relocation upon production and endocrine traits of dairy cows. Joumal of Dairy Science 66 466-474

WILLETT, L. B. \& ERB, R. E. 1972 Short term changes in plasma corticoids in dairy cattle. Journal of Animal Science 34 103-111

WILLIAMS, G. L. 1990 Suckling as a regulator of postpartum rebreeding in cattle: a review. Journal of Animal Science 68 831-852 